\title{
Potato Harvester for Smallholder Producers
}

\author{
Dagninet Amare ${ }^{1}$, Geta Kidanemariam ${ }^{2}$, Wolelaw Endalew ${ }^{1}$, Seyife Yilma ${ }^{3}$ \\ ${ }^{1}$ Bahir Dar Agricultural Mechanization and Food Science Research Centre, Bahir Dar, Ethiopia \\ ${ }^{2}$ Institute of Technology, Addis Ababa University, Addis Ababa, Ethiopia \\ ${ }^{3}$ Institute of Technology, Bahir Dar University, Bahir Dar, Ethiopia
}

Email address:

dagnnet@gmail.com (D. Amare)

\section{To cite this article:}

Dagninet Amare, Geta Kidanemariam, Wolelaw Endalew, Seyife Yilma. Potato Harvester for Smallholder Producers. International Journal of Mechanical Engineering and Applications. Vol. 3, No. 6, 2015, pp. 103-108. doi: 10.11648/j.ijmea.20150306.11

\begin{abstract}
The post harvest loss of potato in Ethiopia is more than $25 \%$ which includes harvesting loss. To minimize the harvesting loss, providing appropriate equipment (technology) is essential. As a result, a study was carried out to develop and select suitable potato digger for small holder potato producers. Comparisons were conducted on three types of potato diggers; traditional plow, AIRIC potato (ground nut) digger and third newly developed potato digger (BD digger). Bio physical and socio economic data were taken using a structured data sheet. Data was analyzed using descriptive statistics and non parametric statistical tests. The BD digger gave the highest average exposing efficiency (92.40\%) and lowest tuber damage (0.81\%). The average digging loss for BD digger, with $0.25 \mathrm{ha} / \mathrm{hr}$ working capacity, was the lowest (7.61\%). The Kruskal Wallis analysis revealed highest positive rank sum (107) for the digger. Overall, farmers' ranked BD digger as best performing. The financial analysis indicated that BD digger has a net benefit advantage of ETB 522 in one harvesting season from a quarter hectare of land. Thus, it is important to promote the technology as a means of post harvest loss reduction.
\end{abstract}

Keywords: Potato Digger, Exposing Efficiency, Digging Loss, Kruskal Wallis, Likert Scale

\section{Introduction}

Potato (Solanum tuberosum L.) is the fourth most important food crop in the world [1]. It provides high nutrition and is an adaptive species for climate change. Potatoes use less water per nutritional output than all other major food sources and can be grown across Africa [2]. Potato provides more food per unit area than any other major staple crop. They are the perfect food and one of the few that can actually sustain life on its own. Thus, it has significant impact on providing nutrition to families, increasing household income and providing surplus to the wider market [2].

Ethiopia has possibly the highest potential for potato production than any country in Africa with $70 \%$ of the 13.5 million ha of arable land suitable for potato cultivation. Over one million highland farmers could grow potatoes in Ethiopia. Two of the three known agro-ecologies woyina dega (15002300 masl) and dega (above 2300 masl) exhibit the best out grower potato production [3]. However, the potato is widely regarded as a secondary non-cereal crop in part because it has never reached the potential that it has in supporting food security. It is estimated that 160,000 ha are now planted annually by approximately one million potato farmers [2]. The Amhara region produces potato on 71325.18 ha land [4]. The total yield harvested was 339353.37 tons with average productivity of 4.8 tons per hectare. The west Amhara, where this research was conducted, accounted for $98.79 \%$ of the regional hectarage and $98 \%$ of the production volume. Potato is grown mainly on small farms. Ethiopia has a much higher potential to increase agricultural production of the crop through use of improved seeds and undertaking technological innovation that facilitate the management and reduce post harvest losses [2] [5] [1].

Post harvest loss (20-25\%) is one of the major problems in the potato production. Among this is physical damage [6], due to the digging (lifting) of the tubers by hoe or local plow [3] [1]. This entails that significant loss is incurred to the small holders that could have helped in nutrition, food security and income generation [7]. Potato yield productivity has increased far more than 24 tons per hectare due to adoption of new varieties [2]. However, post harvest loss reduction efforts have not been tailored well. Harvesting loss reduction helps increasing income, achieve food security, and subsequent storage lose reduction [1]. Thus, to reduce harvesting losses, appropriate technologies should be 
developed and promoted. Hence, this study was initiated with the aim of selecting, evaluating and demonstration of potato diggers that reduce current harvest loss, to smallholder producers.

\section{Material and Methods}

\subsection{Study Site Description}

This experiment was conducted in Amhara national regional state $\left(9^{0} 21^{\prime}\right.$ to $14^{\circ} 0$ ' $\mathrm{N}$ latitude and $36^{\circ} 20$ ' to $40^{\circ} 20^{\prime}$ E longitude) of Ethiopia. West Gojam and Awi zones are the two locations [8].

\subsection{Methods}

In order to achieve the development of the desirable potato lifter that could be adopted widely by the farmers, three steps were followed. They are assessment of existing skill and knowledge, modification from existing technologies, testing of the newly modified technology and ultimately on farm evaluation and demonstration.

Phase I. assessment of the traditional practice and the existing technology

During assessment of the traditional potato harvesting practice of two types of potato harvesting techniques namely using traditional plow and by using hoe were found being implemented.

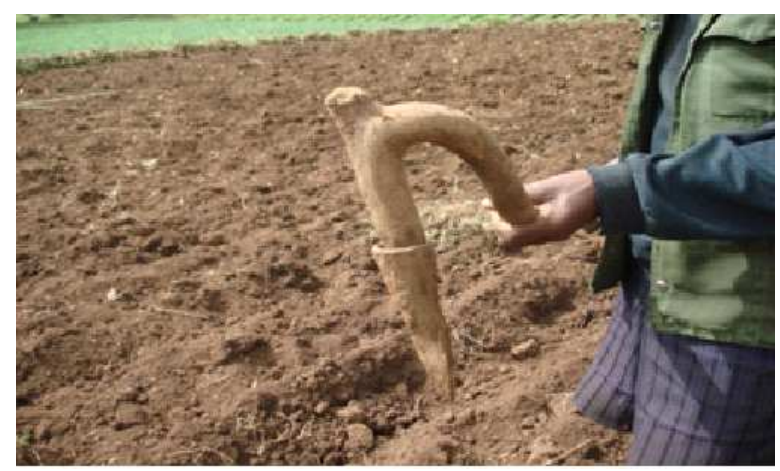

Figure 1. Hand hoe.

Hand hoe: It is manual and low efficient. It is simple and can be used by children that are usually the dominant harvesters of potato. Its cost is 40ETB.

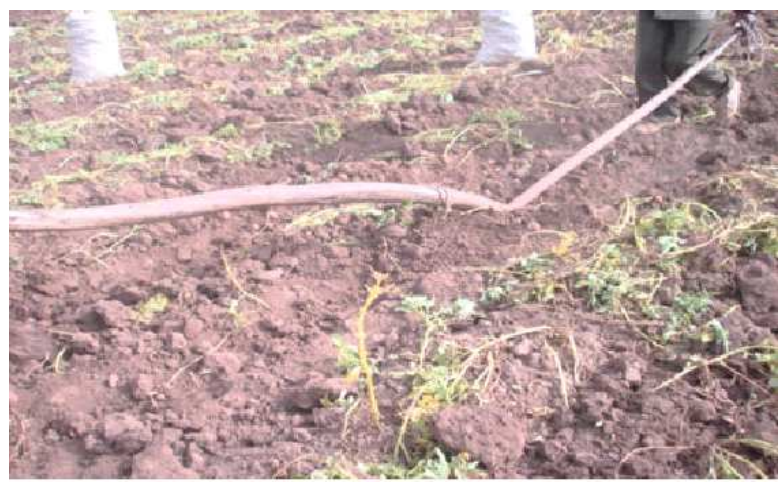

Figure 2. Potato digging in Awi.
Traditional plow: the implement is described as having poor exposing efficiency, incurs significant tuber damage and low working capacity.This implement is commonly used for hoeing maize crop and some other weeding activities. Average cost is 200ETB.

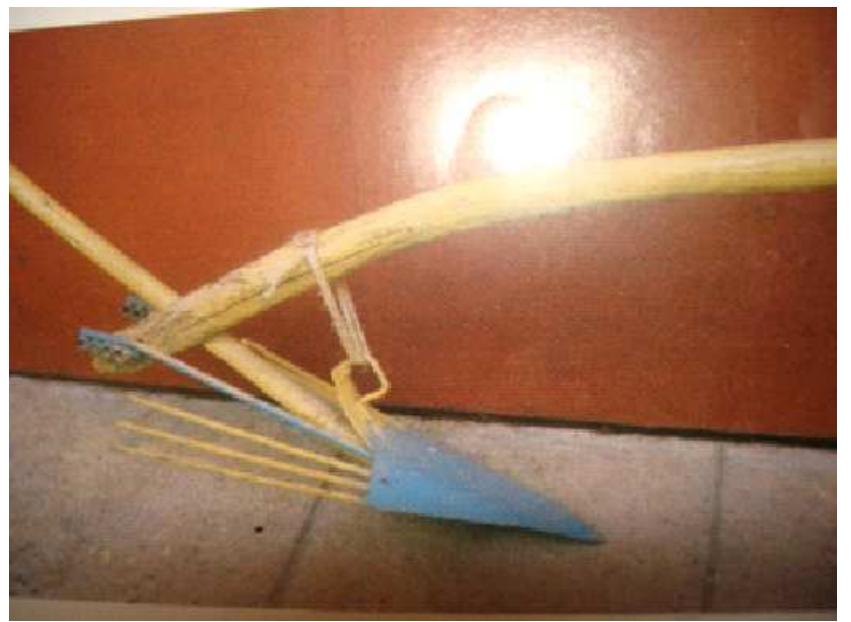

Figure 3. Melkassa ground nut digger.

Ground nut digger: it is made of a $2.5 \mathrm{~mm}$ thick sheet metal and deformed bar with diameters of $10 \mathrm{~mm}$ and 12 $\mathrm{mm}$ with overall dimension of length of $830 \mathrm{~mm}$ and 520 $\mathrm{mm}$. It has a field capacity of $72 \mathrm{~m}^{2} / \mathrm{hr}$ and exposing efficiency of $67.47 \%$. It is animal drawn and has estimated cost of 200 ETB.

Phase II. Deciding on the design and the factors

The basic design parameters were selected based on the constraint and the capacity to mitigate. They included smooth or rounded lifter edge, increased lifter depth (by 2-5 $\mathrm{cm}$ ), reduced damage level by $5-10 \%$ and increased exposing efficiency by $5 \%$ compared to the available technology. In general, the new potato digger was projected to have a maximum tuber damage of $5 \%$ and exposing efficiency of $85 \%-90 \%$. The power source was supposed to be animal drawn, as it is the common draft force, and a price of less than 10USD which is the current price of the local plow. Working width and depth of $30-40 \mathrm{~cm}$ and $15 \mathrm{~cm}-20 \mathrm{~cm}$ were set as target points while the raw material for the production was considered to be locally available.

The general principle for soil and implement interaction was recognized. The draft was influenced to a greater extent by the lift angle than by side angle. Based on this theory, different options were used to set angle of lifting $(\alpha)$ and cutting ( $\beta)$ angles [9] [10]. For this implement $\alpha=15^{\circ}$ was selected while $\beta$ has different values for different shape of the tip which spans from $45^{\circ}-90^{\circ}$. Referring on mechanized system of potato digger or the theoretical technology options, the desired implement was designed to have either triangular tip with bent sheet, triangular tip with rod, ring wing or oval tip with rod. Ultimately, decision Matrix (Table-1) was used for the selection of the desired Potato digger. Accordingly, the oval tip with rod was ranked first. The draft force required [11] was calculated as $42.66 \mathrm{kgf}$. 
Table 1. Decision matrix.

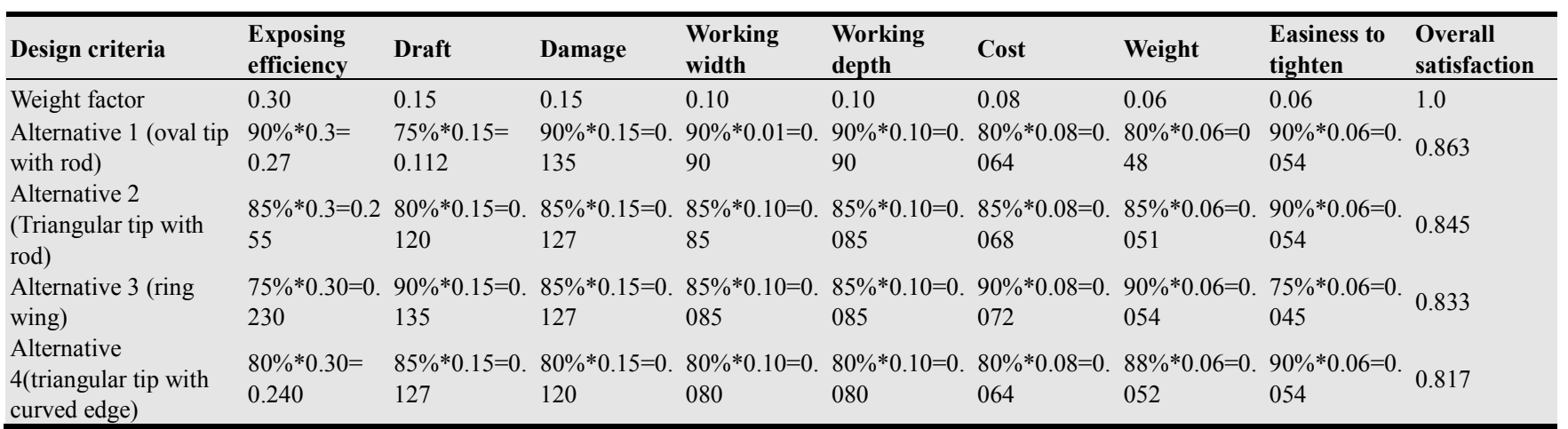

Phase III. Development and testing of the BD digger

Based on the parameters set above, the new digger was developed. After the development, the digger was tested on the center's farm land. Ultimately, the digger was considered as another technology option and was included as a treatment. Measurements on soil moisture, row spacing, working depth, working width and digging depth were measured accordingly. Exposing efficiency was calculated using amount of exposed tubers at first and by hand digging at last. Field capacity of the implement, tuber damage, exposing efficiency, digging loss and damage were calculated accordingly.

\subsection{Treatments}

The treatments were Melkassa (AIRIC) potato lifter, traditional plow (Awi and Adet area plows) and the new potato lifter (BD potato digger).

\section{Testing Condition}

\subsection{Plot Size and Preceding Crops}

The first three tests were conducted Beata kebele of Kosober area in Awi Zone. The plot sizes were $32 \mathrm{~m}^{*} 36 \mathrm{~m}$, $26 \mathrm{~m} * 25.6 \mathrm{~m}$ and $24.7 \mathrm{~m} * 20 \mathrm{~m}$ in the first year of the project. The weeding frequency for both plots was two times. Previous crop grown was field pea and Teff, Barely for first and second plots. The second two tests were conducted at Adet agricultural research center in West Gojam Zone. The sample plot sizes were $27 \mathrm{~m} * 32 \mathrm{~m}$ and $25 \mathrm{~m} * 30 \mathrm{~m}$ in the second year of the project.

\subsection{Potato Varieties}

In Awi, the local variety called Abalo or Ater Abeba was the variety where the implements were tested for both plots. However, at Adet agricultural research center, improved potato varieties named Gudenie for the first plot and Jalenie for the second were used. These two improved potato varieties productivity was low, compared to the research output, during testing due to irrigation water shortage. This may influence the efficiency of the implements. However, it was assumed to influence all of the implements similarly.
As a result, the output during this testing was considered as the most proximate.

\subsection{Draft Force}

In Awi, the implements were pulled by pair of horses, the weight of the horses were approximately $320 \mathrm{~kg}$ and $350 \mathrm{~kg}$ In Adet, the implements were pulled by pair of Ethiopian oxen, with estimated weight of $450 \mathrm{~kg}$ and $480 \mathrm{~kg}$ respectively. The traditional plow shear used in Awi area is small and its length is $26 \mathrm{~cm}$. The traditional plow shear used in Adet area is large and its length is $60 \mathrm{~cm}$. The trail was done by the farmers themselves. During the test, the animals breathing and walking condition was considered. No signs of stress were observed.

\subsection{Soil Type}

At Adet, the type of soil was clay and previous crop grown was Finger Millet for both plots. Soil moisture was 13.63\% and $18.65 \%$ for the first and second plots. The trail was done by the farmers. In Awi, the type of soil is sandy loam and moisture content was between $20-28 \%$.

\subsection{Data Collection and Data Analysis}

Physico- mechanical data collection: measurements were performed from 3 plots and 3 rows at each treatment. A total of 27 observations in Awi and 18 observations at Adet area for each implement were taken. Blocking was done on row bases of each plot as a replication. The treatments were assigned randomly for each plot. Three rows for each replication were taken. All tubers at the first digging operation were collected and weighed. Then the measurement was repeated with the same row for the second digging operation by the implements. To evaluate the digging (exposing) capacity of each technology, hand digging using hoe was done over a depth deeper than 1 st and 2nd digging operation. This was repeated at three places of each sample rows. Estimation of human labor requirement for the hoe operation was conducted using male and female adult farmers using a stopwatch on sample rows of known length and width.

Users'feedback collection: feedbacks from seven farmers 
who were directly involved in the utilization and testing of the implement were collected immediately after the test. A formal data sheet was prepared and used to harness the reflection of farmers on the three diggers. A 3 level likert scale was prepared to harness the attitude of farmers. The scales used are fair (1), good (2) and very good (3). Heavy (1), medium (2) and light (3) likert scales were assigned for weight, draft requirement and tuber damage. Individual rating was made by each of the farmers for each of the three diggers on eight (8) performance criteria of the implements.

Data Analysis: AutoCAD 10 was used to analyze the cutting angle implement relationship and to design the new digger. Data were analyzed using simple descriptive statistics and non parametric tests. Stata 11 was used for data analysis.

Financial analysis: The financial analysis of a typical Ethiopian smallholder farmer is calculated. Average potato land of 0.25 ha and average output of 20 tons/ha are assumed. The average yearly farm gate price is estimated to be $6 \mathrm{ETB}$.

\section{Results and Discussion}

\subsection{General Observation}

The traditional plow has significant difference in area both in size and draft animal used. Around Adet the farmers use a big plow shear with length of $50-60 \mathrm{~cm}$ and ox as draft animal. In Awi, the farmers use a relatively smaller shear with length of $25-30 \mathrm{~cm}$ and the draft animal used are horses. As an obvious fact, as the size of the plow shear increases the exposing efficiency increases correspondingly.

\subsection{Size and Exposing Efficiency Interaction}

Table 2. Exposing efficiency and tuber damage of the diggers.

\begin{tabular}{|c|c|c|c|c|c|c|}
\hline \multirow{3}{*}{$\begin{array}{l}\text { Treatment } \\
\text { (digger) }\end{array}$} & \multicolumn{6}{|l|}{ Potato variety } \\
\hline & \multicolumn{2}{|c|}{ Ater Abeba (Local variety) } & \multicolumn{2}{|c|}{ Gudenie (Improved variety) } & \multicolumn{2}{|c|}{ Jalenie (Improved variety) } \\
\hline & $\begin{array}{l}\text { Exposing } \\
\text { Efficiency,\% }\end{array}$ & $\begin{array}{l}\text { Damage } \\
\text { tubers, } \%\end{array}$ & $\begin{array}{l}\text { Exposing } \\
\text { Efficiency,\% }\end{array}$ & $\begin{array}{l}\text { Damage } \\
\text { tubers, } \%\end{array}$ & $\begin{array}{l}\text { Exposing } \\
\text { Efficiency, \% }\end{array}$ & $\begin{array}{l}\text { Damage } \\
\text { tubers, } \%\end{array}$ \\
\hline Traditional plow (Awi) & 85.91 & 1.69 & - & - & - & - \\
\hline Traditional plow (Adet) & - & - & 95.96 & 0.23 & 94.63 & 0.02 \\
\hline AIRIC digger & 87.06 & 1.61 & 95.97 & 0.19 & 93.27 & 0.14 \\
\hline BD digger & 89.12 & 1.21 & 97.19 & 0.28 & 97.40 & 0.12 \\
\hline
\end{tabular}

The working speed influences the exposing efficiency. In most cases, when the speed decreases the exposing efficiency increases. Thus, speed and exposing efficiency are inversely related. However, the working capacity decreases as the speed decreases. On the improved varieties (Gudenie and Jalenie, have bigger tuber size than local variety), the exposing efficiency of all technologies become effective and higher than $90 \%$ (Table-2). This shows that the size of the variety is directly related to the exposing efficiency.

The improved variety has less mechanical damage than the local variety. So, it seems the improved variety tubers have hard skin. In all cases, BD digger has better exposing efficiency than all implements. This is due to its shape and big size of the shear. It also has better working depth and width. The damage was lowest due to the shape and smoothness of the cutting edge. Our hypothesis were realized,by having appropriate angle of the digger shear that the depth of lifter was increased by $2.4 \mathrm{~cm}$ and the damage was decreased by $3-5 \%$ compared to the traditional system and the available technology. Further, the exposing efficiency (output) was increased by $2-3 \%$. During the demonstration, the farmers reflected similar performance evaluation results.

\subsection{Draft Animals and Working Capacity}

The horses have a better working capacity than those in Adet, pair of oxen (Table-3). The reasons for the higher working capacity could be the smaller shear size of the plow that requires low draft force compared to the one with larger shear size. Further, due to the mild weather conditions in Awi, the soil could be wet compared to that of Adet that was dry at the time of the test.

The performance of the BD digger on exposing efficiency, digging loss and working capacity is higher than the alternative technologies evaluated. Besides, the damage loss during harvesting is the lowest compared to others except hand hoe.

Table 3. Working depth and width of the diggers.

\begin{tabular}{|c|c|c|c|c|c|c|}
\hline \multirow[b]{2}{*}{ Treatment } & \multicolumn{3}{|c|}{ Drawn by horses Awi zone } & \multicolumn{3}{|c|}{ Drawn by oxen Adet } \\
\hline & $\begin{array}{l}\text { Working } \\
\text { depth }(\mathrm{cm})\end{array}$ & $\begin{array}{l}\text { Working } \\
\text { width }(\mathrm{cm})\end{array}$ & $\begin{array}{l}\text { Working } \\
\text { capacity (ha/hr) }\end{array}$ & $\begin{array}{l}\text { Working } \\
\text { depth }(\mathrm{cm})\end{array}$ & $\begin{array}{l}\text { Working width } \\
\text { (cm) }\end{array}$ & $\begin{array}{l}\text { Working capacity } \\
\text { (ha/hr) }\end{array}$ \\
\hline Traditional plow(Awi) & 7.46 & 25.48 & 0.20 & -- & - & - \\
\hline Traditional plow (Adet) & - & - & - & 9.5 & 25.75 & 0.185 \\
\hline AIRIC digger & 7.90 & 35.49 & 0.208 & 10.95 & 28.08 & 0.174 \\
\hline BD digger & 9.67 & 37.38 & 0.23 & 11.65 & 32.16 & 0.187 \\
\hline
\end{tabular}


Table 4. Overall performance.

\begin{tabular}{lllll}
\hline Parameter & Damage (\%) & Exposing efficiency (\%) & Digging loss (\%) & Working capacity (ha/hr) \\
\hline Hand hoe & 0.78 & 100 & - & 0.0025 \\
Local Maresha & 1.06 & 89.164 & 10.836 & 0.219 \\
AIRIC & 1.03 & 90.069 & 9.923 & 0.217 \\
BD digger & 0.81 & 92.391 & 7.609 & 0.247 \\
Average & 0.92 & 92.906 & 9.456 & 0.171 \\
\hline
\end{tabular}

\subsection{Farmers' Feedback}

The result indicated that exposing efficiency, working width and easiness of tightening were rated as having a significant difference $\left(x^{2}=14.74, \mathrm{p}=0.005\right)$ among the local, BD and AIRIC diggers signifying that the AIRIC digger was found superior than the others according to the rating done by farmers. Similarly, the chi-square analysis of the working depth of the different diggers indicated the presence of significant $\left(x^{2}=10.25, \mathrm{p}=0.036\right)$ difference according to their rating. In contrast, the three scale likert measurement for draft requirements of the three diggers showed absence of such significant $\left(x^{2}=6.25, \mathrm{p}=0.181\right)$ difference in their draft requirements. On the other hand the rating for tuber damage showed presence of significant $\left(x^{2}=21, \mathrm{p}=0.000\right)$ difference and making the local plow as having the highest tuber damage. An overall rating on the weight of the plows for transportation indicated the absence of statistically significant $\left(x^{2}=4.77, \mathrm{p}=0.311\right.$ ) difference in weight among the three plows. However, the appearance rating indicates that there is significant difference $\left(x^{2}=17.67, \mathrm{p}=0.001\right)$ in the appearance of the plows which showed that the BD digger is somehow better than others.

Table 5. Kruskal-Wallis equality-of-populations rank test

\begin{tabular}{lllll}
\hline Plow type & Observation & Rank Sum & $\boldsymbol{x}^{\mathbf{2}}$ & \multicolumn{1}{c}{ df } \\
\hline Local plow & 7 & 34.00 & $10.827^{*} * *$ & $12.738^{* * *}$ \\
BD digger & 7 & 107.00 & & \\
AIRIC digger & 7 & 90.00 & \\
\hline
\end{tabular}

*** Significant at $1 \%$ level of confidence

The results of the Kruskal Wallis analysis indicated that the BD digger has the highest positive rank sum and it is significantly higher than the other two diggers. This implies that according to the farmers ranking, the $\mathrm{BD}$ digger is the most efficient potato digger among the diggers incorporated in this test. This was also confirmed during the overall ranking where the farmers put the BD digger, the AIRIC digger and the local plow in order of highest to lowest preference respectively.

\subsection{Financial Analysis}

The net benefit from $\mathrm{BD}$ digger is higher than the most common harvester, traditional maresha.

Table 6. Comparative financial profitability.

\begin{tabular}{|c|c|c|c|c|}
\hline Parameter & Hoe & Traditional maresha & AIRIC & BD digger \\
\hline Output & 5 tons & 5 tons & 5 tons & 5 tons \\
\hline Income (ETB) & 30000 & 30000 & 30000 & 30000 \\
\hline Material cost(ETB) & 40 & 200 & 250 & 250 \\
\hline Labor cost at working capacity(ETB/ha) & 2000 & 68.50 & 69.12 & 60.73 \\
\hline Tuber damage cost (ETB) & 234 & 2120 & 2060 & 1620 \\
\hline Digging loss(ETB) & - & 216.72 & 198.46 & 152.18 \\
\hline Net benefit & 27526 & 27394.8 & 27422.4 & 27917.1 \\
\hline
\end{tabular}

\section{Conclusion and Recommendation}

As to the assumption, the exposing efficiency was averagely increased by around $4 \%$ compared to the traditional lifter. Further, the working depth was increased by more than $3 \mathrm{~cm}$ compared to the traditional maresha lifter The modified BD potato digger has the qualities desired at the start of the project. Farmers ranked it the best among the available technologies that fit their production system. The financial analysis showed an advantage net benefit of more than 500 ETB from a hectare of potato by using the
BD digger. Given the issue of food security in the country, a small increase in total output contributes a lot to the overall food availability in the country. Even in the production areas where there is the highest degradation and food productivity is low, a small increase in quality and quantity of potato produced helps to tackle food insecurity. Hence, reduction of this post harvest loss becomes very indispensable. Therefore, demonstration of the technology with better performance is essential. According to the test results it is better to demonstrate the best technology in regard of exposing efficiency (BD Digger) to the farmers. Thus, demonstration at large scale to all potato producing 
areas of the region as well as to the country should be undertaken. Besides, the preference of the small scale farmers along with the durability of the implement should be studied for further improvement.

\section{References}

[1] Hakan Kibar, 2012. Design and Management of Postharvest Potato (Solanum Tuberosum L.) Storage Structures. Ordu Univ. J. Sci. Tech., 2(1):23-48.

[2] Vita and IPF (Irish Potato Federation), 2014. Potatoes in Development: A Model of Collaboration for Farmers in Africa. Pdf doc.

[3] Tesfay, A., 2008. Potato Production Manual. Amharic Version printed in 1999 Ethiopian Calendar.

[4] CSA, 2003. Ethiopian Agricultural Sample Enumeration 2001/02. Results for Amhara Region. Statistical Report on Area and Production of Crops. Part II. A.
[5] Tewari V. K., A. Ashok Kumar, Satya Prakash Kumar, Brajesh Nare, 2012. Farm mechanization status of West Bengal in India. Journal of Agricultural Science and Review, 1(6):139146.

[6] Akeson W. R., Fox S. D., Stout E. L., 1974. Journal of the American Society Sugar Beet Technologists, 18:125-135. Dawit, A., 2004. Agricultural Technology evaluation, adoption and marketing. Part 2. Proceedings of the workshop held to discuss the socioeconomic research results of 1998-2002. August 6-8, 2002, Addis Ababa, Ethiopia, ERO, 2004.

[7] BoFED (Bureau of Finance and Economic Development), 2007. Annual statistics for Amhara National Regional State. Bahir Dar, Ethiopia.

[8] Kaburaki, H., and Kisu, M., 1959. Studies on Cutting Characteristics of Plows. J. Kanto-tosan Agric. Exp. Stn. (Translation 79, Scientific Information Dep., NIAE, Silsoe, UK).

[9] Sommer, M., 1999. Animal Traction in Rain Fed Agriculture: In Africa and South America Eschborn.

[10] Newbauer, K., 1989. Agricultural Machinery, Prague. 